\title{
STEROIDAL GLYCOSIDES OF FURCRAEA SELLOEA AND THEIR BIOLOGICAL PROPERTIES AGAINST DIFFERENT SCHISTOSOMA MANSONI STAGES
}

\author{
H. A. El-Nahas ${ }^{1}$, E. S. Abdel-Hameed ${ }^{1}$, A. A. Sabra ${ }^{2}$ and E. A. El-Wakil ${ }^{1}$
}

${ }^{1}$ Laboratory of Medicinal Chemistry and ${ }^{2}$ Laboratory of Pharmacology

Theodor Bilharz Research Institute Warrak El-Hadar, Giza, Egypt

\begin{abstract}
تم اخضاع اوراق نبات فوركاريا سيلوي (عائلة الصبارات) لعمليات استخلاص تجزيئي

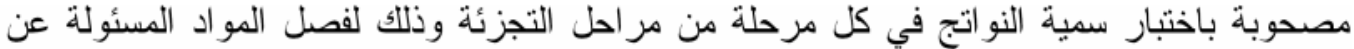

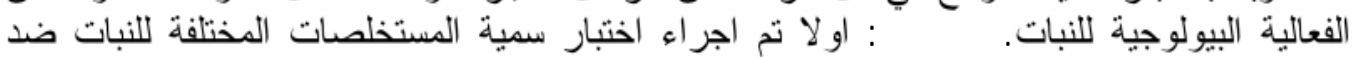

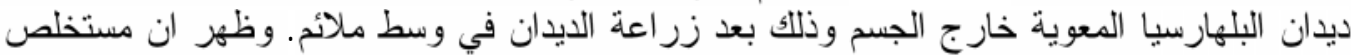

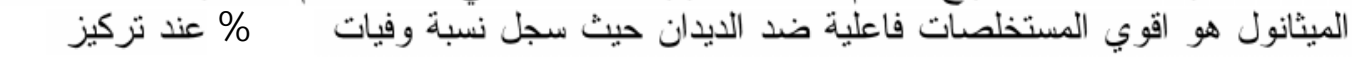

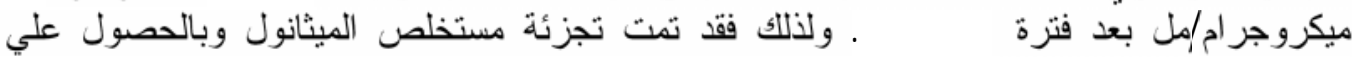

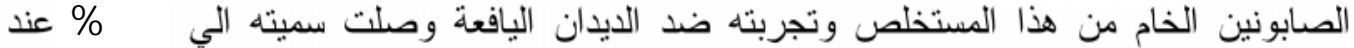

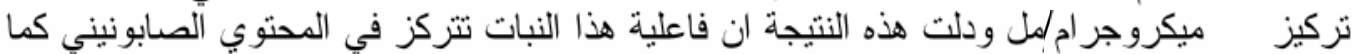

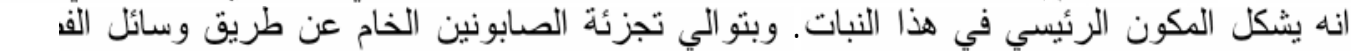

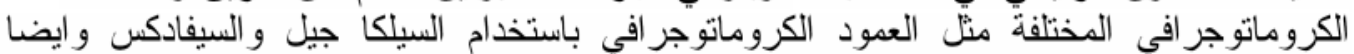

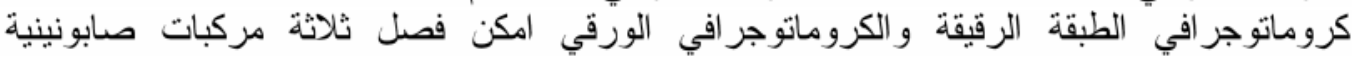

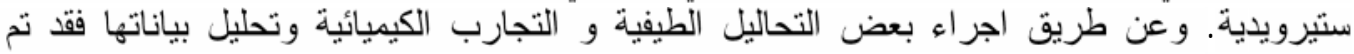

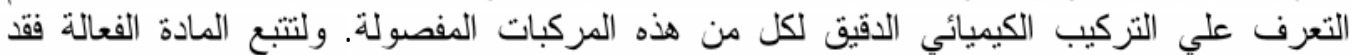

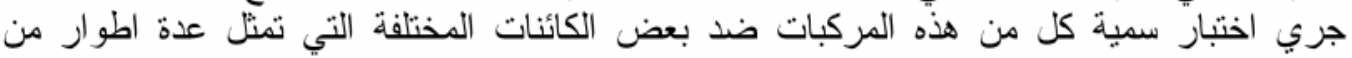

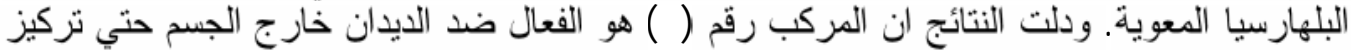

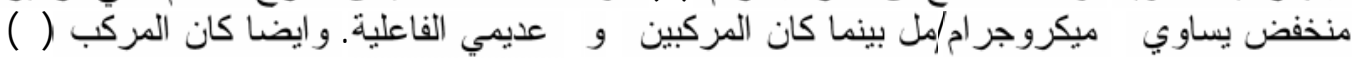

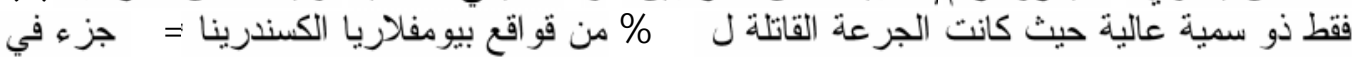

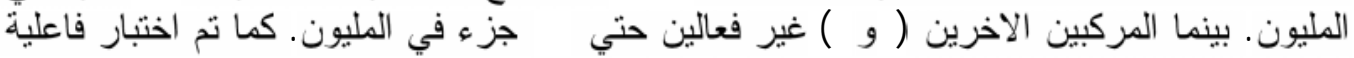

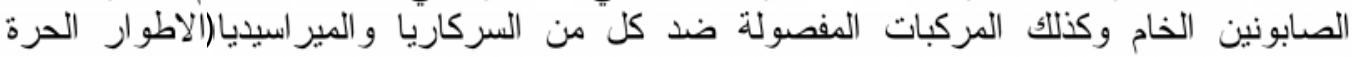

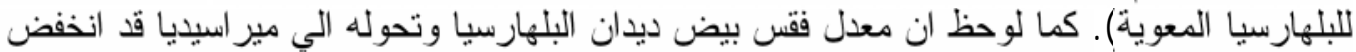

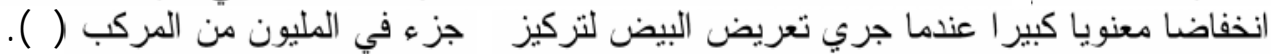

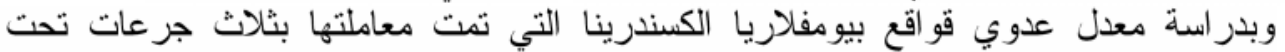

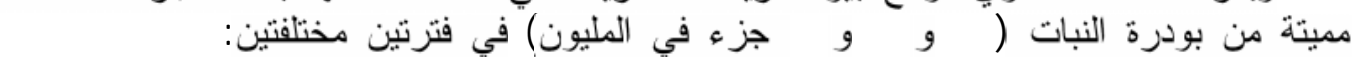

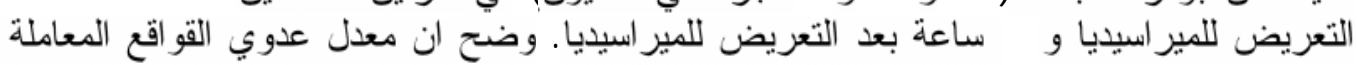

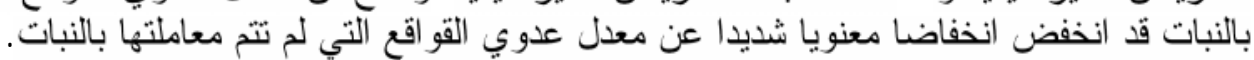

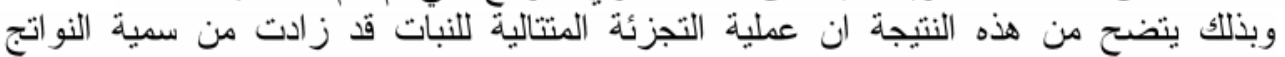

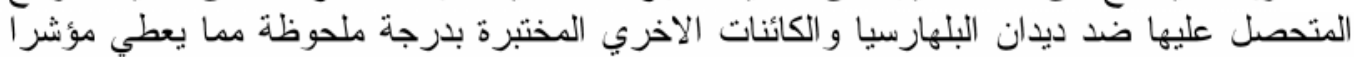

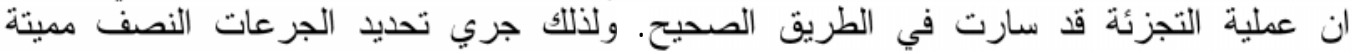
(LD50) r, ro7

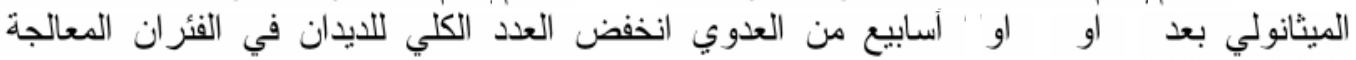

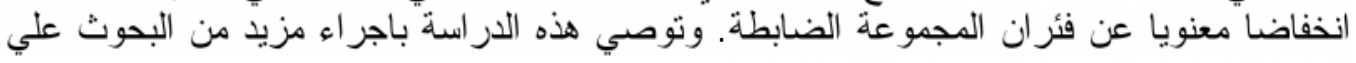

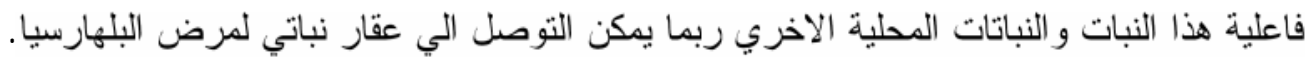

Furcraea selloea C. Koch dry powder (Family Agavaceae) was subjected to a bioassayguided fractionation technique to isolate the active constituents responsible for the potency of this plant. The antischistosomal impact of different extracts of the leaves of F. selloea was 
screened against adult Schistosoma mansoni worms in vitro using a well established culture media. The methanol extract of the plant showed the highest activity as S. mansoni worms recorded $100 \%$ mortality at $50 \mu \mathrm{g} / \mathrm{ml}$ after 24 hours. Owing to the high potency of the crude saponins obtained from the methanolic extract (100\% mortality at $20 \mu \mathrm{g} / \mathrm{ml}$ ), it was submitted to chromatographic separation using silica gel and Sephadex columns as well as preparative thin layer chromatography. Three steroidal saponins (I-III) were isolated and their structures were elucidated using some spectroscopic and chemical methods as follows: 6-O- $\beta$ - $D$ glucopyranosyl $(1 \rightarrow 4)$ - $\beta$-D-glucopyranoside chlorogenin $(I)$, 3-O- $\beta$-D-glucopyranosyl- $(1 \rightarrow 4)$ $\beta$-D-glucopyranoside crestagenin (II) and 3-O- $\beta$-D-glucopyranosyl- $(1 \rightarrow 3)-\beta$-D- glucopyranosyl- $(1 \rightarrow 3)-\beta$-D-xylopyranoside gloriogenin $(\boldsymbol{I I I})$.

Bioassay screening of the isolated saponins (I-III) were carried out against certain Schistosoma mansoni stages. Compound III only proved to possess antischistosomal activity against $S$. mansoni worms at concentration as low as $5 \mu \mathrm{g} / \mathrm{ml}$, while compounds I and II were inactive. Also, test against B. alexandrina snails revealed that only saponin III has high molluscicidal activity $\left(L C_{90}=6 \mathrm{ppm}\right)$ whereas the other two saponins did not show any activity up to 50 ppm after 24 hours exposure. Different concentrations of the crude and the isolated saponins were evaluated against S. mansoni free larval stages (cercariae and miracidia). Hatchability of S. mansoni ova was markedly depressed when exposed to 6 ppm of compound III. The infection rate of B. alexandrina snails was significantly reduced when snails were exposed to three sublethal concentrations of the dry plant powder. Determination of the acute oral toxicity of F. selloea methanol extract against mice was carried out. When three groups of mice infected with S. mansoni were treated orally with a single dose of $2500 \mathrm{mg} / \mathrm{kg}$ of F. selloea methanol extract either at 2, 4 or 7 weeks post infection, the reduction rate in worm load was significantly lower when compared to infected untreated control.

\section{INTRODUCTION}

Intestinal schistosomiasis is caused by the helminth Schistosoma mansoni and afflicts millions of people in many tropical and subtropical countries. ${ }^{1}$ Control of this disease involves chemotherapy along with mollusciciding the water bodies infested with the parasites intermediate host; snails of the genera Biomphalaria. Synthetic molluscicides and chemotherapy are relatively expensive and therefore not accessible in the developing countries. $^{2}$

Praziquantel is still the drug of choice for schistosomiasis control, yet in the recent years, a number of reports indicated the apparent failure of the recommended doses of PZQ to yield the expected cure rates in human population of Kenya, ${ }^{3}$ Brazil, $^{4}$ Senegal ${ }^{5,6}$ and Egypt. $^{7}$

Plants have provided a number of useful clinical agents that prove to have considerable potentials as sources of new drugs. ${ }^{8}$ So the use of medicinal plants which grow abundantly in areas where schistosomiasis is endemic may become a useful complement either as molluscicides or chemotherapy for the control of this disease. However few studies have addressed the use of medicinal plants with antischistosomal activity as treatment for this disease. $^{9,10}$

Furcraea is a plant genus that contains specific compounds of numerous medicinal purposes. The dry powder of $F$. selloea plant (Agavaceae) was previously reported to possess strong molluscicidal potency against Biomphalaria alexandrina snails. ${ }^{11}$ So it was thoughtful to continue work on this plant and to test the effect of its extracts on $S$. mansoni worms and to subject this plant to chromatographic technique to isolate and identify some of its constituents. This investigation also reported the impact of the isolated compounds on different $S$. mansoni stages such as snails, the larvae, $S$. mansoni ova and adult worms. The effect of the plant on the infectivity of $S$. mansoni to B. alexandrina and on worms in vivo was also evaluated.

\section{EXPERIMENTAL}

\section{Plant Material}

Furcraea selloea C. Koch plant (Family Agavaceae) was collected from El-Orman Botanical Garden, Giza, Egypt. The plant was identified by Mrs. Traes Labib, general 
manager and head of specialists of Plant Taxonomy in this Garden. The plant leaves were shade dried and powdered by electric mill.

\section{Organisms and animals}

1- Schistosoma mansoni adult worms used in the in vitro test were obtained from Schistosoma Biological Supply Center (SBSC), Theodor Bilharz Research Institute through perfusion of mice experimentally infected with $S$. mansoni cercariae.

2- Biomphalaria alexandrina snails, the intermediate host of Schistosoma mansoni were collected from irrigation canals in Giza governorate. Snails (10-12 mm shell diameter) were maintained in laboratory under optimum conditions.

3- S. mansoni cercariae and ova were obtained from infected $B$. alexandrina snails and liver of infected mice respectively.

4- Adult male CD-1 Swiss albino mice weighing $20 \pm 2 \mathrm{~g}$ at the beginning of the experiment were obtained from Theodor Bilharz Research Institute.

\section{Extraction and preparation of crude saponins:}

About $50 \mathrm{~g}$ of $F$. selloea dry powder was separately extracted using different solvents as reported previously. ${ }^{11}$ Also, the crude saponins $(50 \mathrm{~g})$ were prepared from the dry plant powder $(1.5 \mathrm{Kg})$ as mentioned in the same study.

\section{Bioassay procedures}

\section{$A$ - In vitro schistosomicidal activity}

The in vitro tests of different concentrations of the prepared extracts, crude saponins and the pure isolated compounds were carried out using adult S. mansoni worms in culture medium. The medium consisted of RPMI-1640 supplemented with fetal calf serum and sterilizing antibiotics then buffered to $\mathrm{pH}$ 7.4-7.5. Concentrations were run in duplicate and 10 adult male and 10 adult female worms were added to each tested solution, while negative control worms were kept in the media only. All dishes were incubated at $37.2-37.5^{\circ}$ for $48 \mathrm{hr}$ during which the worms motility were microscopically examined after 2, 24 and 48 hr. $^{12,13}$

\section{B- Snails toxicity tests}

Different concentrations of the three isolated compounds were prepared and snails were subjected to these molluscicidal concentrations in triplicate for $24 \mathrm{~h}$ with a similar recovery period at $25+2^{\circ} .{ }^{14}$ Negative control snails were conducted at the same experimental conditions. The $\mathrm{LC}_{50}$, confidence limits, $\quad \mathrm{LC}_{90}$ and slope functions were calculated following Litchfield and Wilcoxon method. ${ }^{15}$

\section{C- Hatchability test}

Duplicate concentrations of the isolated compounds were conducted and supplied with $S$. mansoni ova. The hatchability of these ova was observed under stereomicroscope after different intervals comparing with ova in control test containing distilled water. ${ }^{16}$

\section{D- Cercaricidal and miracidicidal test}

Both the cercaricidal and miracidicidal impact of the isolated compounds was evaluated as previously recommended. ${ }^{17,18}$ The tested solutions were prepared and supplied with freshly-emitted cercariae and miracidia freshly hatched from $S$. mansoni ova. Moralities of both motionless larvae were observed using stereomicroscope after different observation periods: $1 / 4,1 / 2,3 / 4,1$ and $2 \mathrm{hr}$. Thereafter all larvae were killed by Bouin solution and the cumulative mortality percentages were computed.

\section{E- Snails Infectivity tests:}

Biomphalaria alexandrina snails were cleaned thoroughly with dechlorinated tap water then exposed to 6-8 freshly hatched miracidia (1/2-hr age) per snail following the mass infection technique. Groups each of 30 snails were exposed for 24 hours to three sublethal concentrations (20,35 and $50 \mathrm{ppm})$ of the dry plant powder in two ways; either one day pre-exposure to miracidia or one day postexposure to miracidia. Snails were started to be individually examined for infection after 3 weeks by exposing each snail;in a test tube; to direct electric light for $2 \mathrm{hr}$. Snails shedding cercariae were counted as infected ones, while negative snails were re-examined twice weekly during the following 5 weeks till the end of the experiment ( 8 weeks). The infection rates were 
evaluated as the No. of infected snails to those surviving at the first shedding of cercariae. ${ }^{19}$

\section{F- Acute toxicity of $F$. selloea methanol extract}

A pilot trial was conducted using a limited number of animals for determining the acute oral toxicity, 24 mice were divided into four groups each of six mice. These groups received increasing doses of $F$. selloea methanol extract administered orally by gastric intubations from $500 \mathrm{mg} / \mathrm{kg}$ to $4000 \mathrm{mg} / \mathrm{kg}$. Animal groups were observed $24 \mathrm{hr}$ after dosing and mortality data were then subjected to computer analysis (PCS Software, were used) for determination of $\mathrm{LD}_{50}$.

\section{G- Antischistosomal activity of $F$. selloea methanol extract}

Twenty eight Swiss albino mice were infected with 80 cercariae /mouse of the Egyptian (CD) strain of Schistosoma mansoni using the body immersion technique. Guided by the $\mathrm{LD}_{50}$ estimation, the extract was given orally in a single dose of $2500 \mathrm{mg} / \mathrm{kg}$. Infected animals were divided into 4 groups, three of them were treated orally with $2500 \mathrm{mg} / \mathrm{kg}$ either 2, 4 or 7 weeks post infection, while the last group was infected untreated group (Control). All animal groups were sacrificed 9 weeks post infection. Perfusion of the hepatic and portomesentric vessels were performed to study worm burden according to the procedure outlined by Duval and De Witt. ${ }^{20}$

\section{H- Statistical methods}

The $\mathrm{LD}_{50}$ (The dose at which died $50 \%$ of the mice) was evaluated using a computerized program "Pharm/PCS" Version 4.2 (Pharmacological calculation system) by a plot the number of dead mice versus total number of mice in each group against the dose of the drug administered.

The data obtained were summarized by the arithmetic mean and the standard deviation. Statistical analysis of results was carried out using Students t-test. ${ }^{21}$ The degree of significance (probability p-value) was obtained from the corresponding tables.

\section{Fractionation procedures \\ General}

Melting points were determined by a micro melting point apparatus and were uncorrected. IR spectra were measured on a Perkin-Elmer model FT-IR recording spectrophotometer. ${ }^{1} \mathrm{H}-\mathrm{NMR}(270 \mathrm{MHz})$ and ${ }^{13} \mathrm{C}-\mathrm{NMR}(100 \mathrm{MHz})$ spectra were done using TMS as internal standard, DMSO- $\mathrm{d}_{6}$ as solvent and chemical shifts were given in (ppm) scale. Mass spectra were measured on a Finnigan TSQ 700 GC/MS equipped with a Finnigan electrospray source (EI-MS and CI-MS). For detection of sugar, paper chromatography was performed on Whatmann paper No. 1 using descending technique and visualized with aniline phthalate.

\section{Chromatographic isolation of the crude saponins}

Fractionation of the crude saponins of $F$. selloea was carried out using different chromatographic techniques. A glass column $(120 \times 5 \mathrm{~cm})$ packed with silica gel $60(70-230$ mesh, Merck) as stationary phase was first used. The column was successively eluted with pet. ether followed with $\mathrm{CHCl}_{3},\left(\mathrm{CHCl}_{3}\right.$ : $\mathrm{MeOH})$ mixtures and finally pure methanol. Similar obtained fractions were collected together using glass plates coated with silica gel $\mathrm{GF}_{245}$, Merck (TLC). The spots on TLC were visualized by spraying with $40 \% \mathrm{H}_{2} \mathrm{SO}_{4}$ followed by heating in oven at $120^{\circ}$. Two main groups of fractions were obtained from different eluent $\left(\mathrm{CHCl}_{3}\right.$ : $\left.\mathrm{MeOH}\right)$ mixtures.

1- Fractions collected by elution with $\mathrm{CHCl}_{3}$ : $\mathrm{MeOH}$ (90:10) gave residue (4.5 g) was washed with acetone. The residual part (500 $\mathrm{mg}$ ) was subjected to preparative TLC (solvent system $\mathrm{CHCl}_{3}: \mathrm{MeOH}: \mathrm{H}_{2} \mathrm{O} ; 30$ : 10: 1) to give compound $\mathbf{I}(112 \mathrm{mg})$ and compound II (144 mg).

2-Fractions collected by elution with $\mathrm{CHCl}_{3}$ : $\mathrm{MeOH}$ (80:30) gave residue (3.9 g) was purified on Sephadex LH-20 column using methanol as eluent to give compound III (971 mg).

\section{Acid hydrolysis}

Each of the three compounds $(15 \mathrm{mg})$ was refluxed with $4 \mathrm{~N} \mathrm{HCl}(40 \mathrm{ml})$ for 4 hours on water bath then diluted with water and extracted with chloroform. The chloroform 
extract was evaporated to dryness and the aglycone parts were detected by TLC against authentic samples. Sugar units were obtained from the aqueous layer of each saponin by extraction with anhydrous pyridine.The pyridine layer was evaporated to dryness and dissolved in 10\% isopropanol and detected on $\mathrm{PC}$ against authentic sugars using system nBuOH: AcOH: $\mathrm{H}_{2} \mathrm{O} \quad(4: 1: 5)$ and aniline phthalate as visualizing agent.

\section{The Isolated Compounds}

Compound 1 :Amorphous powder, m.p 256$285^{\circ}, \mathrm{R}_{\mathrm{f}} 0.65\left(\mathrm{CHCl}_{3}: \mathrm{MeOH}: \mathrm{H}_{2} \mathrm{O} ; 7: 3: 0.5\right)$. $\mathrm{IR} v_{\max } \mathrm{KBr} 3401,3939,2886,1641,1454$, 1377, 1069, 921, 898, 865 and 642 [ Intensity $898>921$; 25 R- spiroketal]. ${ }^{1} \mathrm{HNMR}$ (DMSO$\left.\mathrm{d}_{6}\right) 0.71(3 \mathrm{H}, \mathrm{d}, \mathrm{J}=5.7 \mathrm{~Hz}, \mathrm{H}-27), 0.78[3 \mathrm{H}, \mathrm{s}$, H-18], 0.88 (3H, s, H-19), 1.12 (3H, d, J=6.8 Hz, H-21), 3.79 (1H, m, H-3), 3.66 (1H,m,H-6) $4.80(1 \mathrm{H}, \mathrm{d}, \mathrm{J}=7.5 \mathrm{~Hz}, \mathrm{H}-1$ of Glc] and 4.88 $(1 \mathrm{H}, \mathrm{d}, \mathrm{J}=7.7 \mathrm{~Hz}, \mathrm{H}-1$ of $\mathrm{Glc}] . \mathrm{CI} / \mathrm{MS} ; \mathrm{m} / \mathrm{z}$ 757[ $\left.\mathrm{M}^{+}+\mathrm{H}\right], 595 \quad\left[\mathrm{M}^{+}+\mathrm{H}-\mathrm{Glc}\right], 433\left[\mathrm{M}^{+}+\mathrm{H}-\right.$ $2 \mathrm{Glc}], 415\left[\mathrm{M}^{+}+\mathrm{H}-2 \mathrm{Glc}-\mathrm{H}_{2} \mathrm{O}\right]$ and 397[ $\mathrm{M}^{+}+\mathrm{H}-$ 2Glc-2H2O].

Compound II: Amorphous powder, m.p 270$272^{\circ}, \mathrm{R}_{\mathrm{f}} 0.53$ [ $\left.\mathrm{CHCl}_{3}: \mathrm{MeOH}: \mathrm{H}_{2} \mathrm{O} ; 7: 3: 0.5\right]$. IR $v_{\max } \mathrm{KBr} 3400,2929,2826,1649,1453$, $1165,1067,918,897,865$ and 582[Intensity of $918>897$; 25S-spiroketal]. ${ }^{1} \mathrm{HNMR}$ (DMSO d $\left.{ }_{6}\right)$ 0.75[3H, s, H-18], 0.85 [3H, s, H-19], 1.12 $(1 \mathrm{H}, \mathrm{d}, \mathrm{J}=6.8 \mathrm{~Hz} ; \mathrm{H}-21], 3.63-3.68(2 \mathrm{H}, \mathrm{dd}$, $\mathrm{J}=0.2,6.9 ; \mathrm{H}-27], 4.11[1 \mathrm{H}, \mathrm{d}, \mathrm{J}=11.50 \mathrm{~Hz}, \mathrm{H}-$ 2]; $4.64(1 \mathrm{H}, \mathrm{m}, \mathrm{H}-16), 4.84(1 \mathrm{H}, \mathrm{d}, \mathrm{J}=7.4 \mathrm{~Hz}$, $\mathrm{H}-1$ of Glc) and $4.94(1 \mathrm{H}, \mathrm{d}, \mathrm{J}=7.6 \mathrm{~Hz}, \mathrm{H}-1$ of Glc]. CI-MS, m/z 755[ $\left.\mathrm{M}^{+}+\mathrm{H}\right], 594\left[\mathrm{M}^{+}+\mathrm{H}-\right.$ Glc], $431\left[\mathrm{M}^{+}+\mathrm{H}-2 \mathrm{Glc}\right], 413,\left[\mathrm{M}^{+}+\mathrm{H}-2 \mathrm{Glc}-\right.$ $\mathrm{H}_{2} \mathrm{O}$ ] and 394 [ $\mathrm{M}^{+}+\mathrm{H}-2 \mathrm{Glc}-2 \mathrm{H}_{2} \mathrm{O}$ ].

Compound III :colorless needles, m.p 276$278^{\circ}, \mathrm{R}_{\mathrm{f}} 0.54$ [BuOH: MeOH: $\left.\mathrm{H}_{2} \mathrm{O} ; 4: 1: 1\right]$. IR $v_{\max } \operatorname{KBr} 3407,2930,2827,1705,1639,1454$, $1072,920,898,812$ and 591[Intensity of $898>$ 920; 25 R-spiroketal]. ${ }^{1} \mathrm{HNMR}$ (DMSO-d 6 ) 0.76 (3H, s, H-19) 0.84 (3H, s, H-18), 1.09 $(3 \mathrm{H}, \mathrm{d}, \mathrm{J}=6.9 \mathrm{~Hz}, \mathrm{H}-27), 1.37(3 \mathrm{H}, \mathrm{d}, \mathrm{J}=7.0 \mathrm{~Hz}$, $\mathrm{H}-21), 4.84$ (1H, d, J=7.5 Hz, H-1 of Glc), 4.97 $(1 \mathrm{H}, \mathrm{d}, \mathrm{J}=6 \mathrm{~Hz}, \mathrm{H}-1$ of $\mathrm{Glc})$ and $5.33[1 \mathrm{H}, \mathrm{d}$, $\mathrm{J}=6.9 \mathrm{~Hz}, \mathrm{H}-1$ of Xylose]. CI/MS, m/z 887 $\left[\mathrm{M}^{+}+\mathrm{H}\right], \quad 725\left[\mathrm{M}^{+}+\mathrm{H}-\mathrm{Glc}\right], 593 \quad\left[\mathrm{M}^{+}+\mathrm{H}-\mathrm{Glc}-\right.$ $\mathrm{Xyl}], 431 \quad\left[\mathrm{M}^{+}+\mathrm{H}-2 \mathrm{Glc}-\mathrm{Xyl}\right], 412, \quad\left[\mathrm{M}^{+}+\mathrm{H}-\right.$
2Glc-Xyl- $\left.\mathrm{H}_{2} \mathrm{O}\right]$ and $394\left[\mathrm{M}^{+}+\mathrm{H}-2 \mathrm{Glc}-\mathrm{Xyl} \quad-2\right.$ $\left.\mathrm{H}_{2} \mathrm{O}\right]$.

\section{RESULTS AND DISCUSSION}

In the present study, the well-established bioactivity guided fractionation was followed. This technique involves systematic fractionation of the dry plant powder accompanied by bioassay tests of each systemic subfraction. The promising fractions were subjected to further fractionation, while the least active fractions were ignored or neglected. Fig (1) illustrates these fractionation steps. The same technique was previously used to isolate an active antischistosomic compound. ${ }^{22}$

\section{Bioassay results}

In this study the viability of $S$. mansoni adult worms was observed during in vitro incubation with various concentrations of the extracts and the isolated compounds. Data showed that the lethal effect was dependent on the chemical concentration and time of incubation.

Gradual concentrations of pet. ether, chloroform, acetone and methanol extracts (Table 1) showed that the first three extracts did not show any effect against worms at 100 $\mathrm{g} / \mathrm{ml}$ for 2 and $24 \mathrm{hr}$. After $48 \mathrm{hr}, 100$ and 50 $\mathrm{g} / \mathrm{ml}$ of pet. ether extract showed a weak schistosomicidal action as almost $20 \%$ of the parasites were dead. In negative control, worms were alive and viable till the end of the experimental period.

As to the methanol extract, 100 and 50 $\mathrm{g} / \mathrm{ml}$ exhibited $100 \%$ mortality in both male and female worms after $24 \mathrm{hr}$ meanwhile at 100 $\mathrm{g} / \mathrm{ml}$, worms began to slow down their motion and crawl after only $2 \mathrm{hr}$. When the concentration of methanol was lowered to 20 $\mathrm{g} / \mathrm{ml}$, worm mortality was $10 \%$ and $20 \%$ for female and male after $24 \mathrm{hr} ; 20$ and $40 \%$ after $48 \mathrm{hr}$. At $10 \mathrm{~g} / \mathrm{ml}$ worms recorded $10 \%$ and $20 \%$ mortality for female and male after $48 \mathrm{hr}$ This clearly indicates that the antischistosomal action is restricted to the methanol extract, so further fractionation of methanol extract was carried out and all subfractions were subjected to series of bioassay tests till crude saponin was prepared (Fig. 1). 


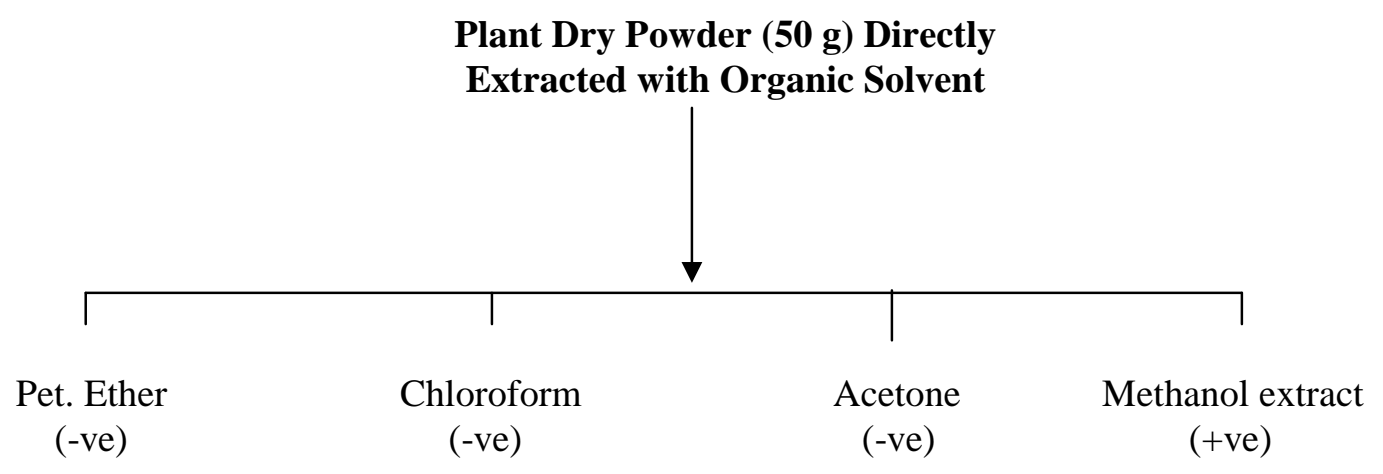

Plant Dry/ powder (1.5 kg)

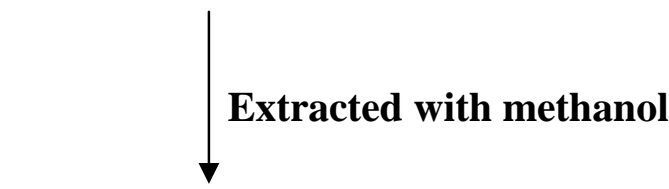

150 g methanolic extract

Dissolved in $\mathrm{H}_{2} \mathrm{O}$ then partitioned with

Pet. ether, $\mathrm{CHCl}_{3}$, EtOAc and n-BuOH

Pet. ether, $\mathrm{CHCl}_{3}$ and EtOAc extract

(-ve)

$\mathrm{n}-\mathrm{BuOH}$

$(+\mathrm{ve})$

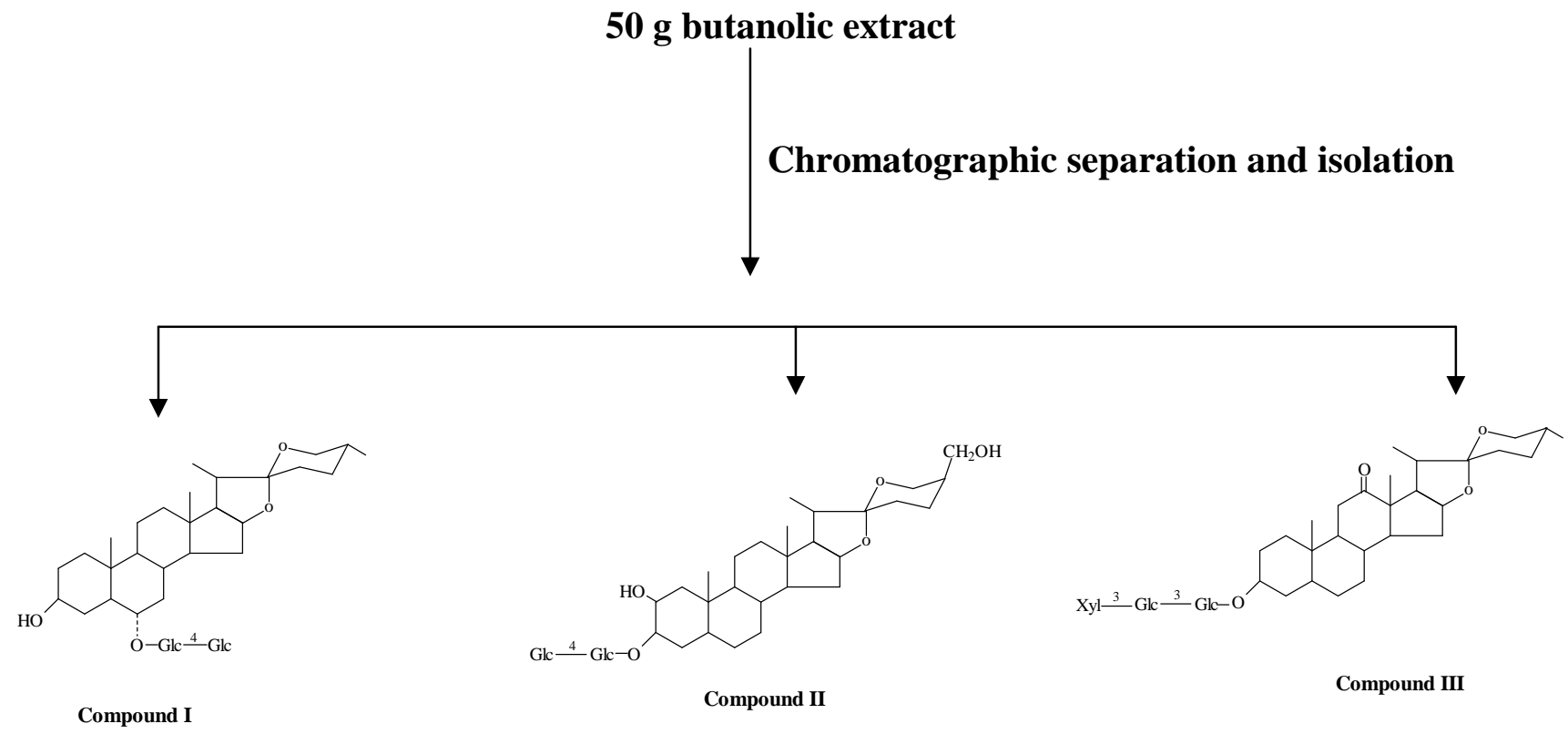

Fig. 1: Diagram illustrating the bioactivity- guided fractionation steps showing the bioassay results of each fraction against $S$. mansoni worms and other stages. 
Table 1: Effect of different extracts and crude saponins of Furcraea selloea against adult S. mansoni worms using in vitro method.

\begin{tabular}{|c|c|c|c|c|c|c|c|}
\hline \multirow{3}{*}{ Extract } & \multirow{2}{*}{$\begin{array}{c}\text { Conc. } \\
(\mathrm{g} / \mathrm{ml})\end{array}$} & \multicolumn{2}{|c|}{ \% Mortality of worms after different observation intervals (hrs) } \\
\cline { 3 - 8 } & & Female & Male & Female & Male & Female & Male \\
\hline \multirow{3}{*}{ Pet. ether } & 100 & 0 & 0 & 0 & 0 & 20 & 30 \\
\cline { 2 - 8 } & 50 & 0 & 0 & 0 & 0 & 20 & 20 \\
\cline { 2 - 8 } & 20 & 0 & 0 & 0 & 0 & 0 & 0 \\
\hline \multirow{2}{*}{ Chloroform } & 100 & 0 & 0 & 0 & 0 & 0 & 0 very active \\
\cline { 2 - 8 } & 50 & 0 & 0 & 0 & 0 & 0 & 0 \\
\hline \multirow{3}{*}{ Acetone } & 100 & 0 & 0 & 0 & 0 & 0 & 0 (weak) \\
\cline { 2 - 8 } & 50 & 0 & 0 & 0 & 0 & 0 & 0 \\
\hline \multirow{3}{*}{ Methanol } & 100 & 0 & 0 & 100 & 100 & 100 & 100 \\
\cline { 2 - 8 } & 50 & 0 & 0 & 100 & 100 & 100 & 100 \\
\cline { 2 - 8 } & 20 & 0 & 0 & 10 & 20 & 20 & 40 \\
\cline { 2 - 8 } & 10 & 0 & 0 & 0 & 0 & 10 & 20 \\
\hline \multirow{3}{*}{$\begin{array}{c}\text { Crude } \\
\text { saponins }\end{array}$} & 100 & 100 & 100 & 100 & 100 & 100 & 100 \\
\cline { 2 - 8 } & 50 & 0 & 0 & 100 & 100 & 100 & 100 \\
\cline { 2 - 8 } & 20 & 0 & 0 & 100 & 100 & 100 & 100 \\
\hline Control & 10 & 0 & 0 & 40 & 60 & 100 & 100 \\
\hline
\end{tabular}

The crude saponins showed a much stronger effect as $100 \%$ worms mortality was recorded after being exposed to $100 \mathrm{~g} / \mathrm{ml}$ for only $2 \mathrm{hr}$. Moreover, microscopical observation of worms showed that they started to die from the first hour. Reducing the concentration to 50 then $20 \mathrm{~g} / \mathrm{ml}$, the mortality rate was still $100 \%$ after $24 \mathrm{hr}$. When worms were treated with 10 $\mathrm{g} / \mathrm{ml}$ for $24 \mathrm{hr}, 40$ and $60 \%$ mortalities were noticed for female and male worms respectively and $100 \%$ in both sexes after $48 \mathrm{hr}$. It is evident from this data that female worms were slightly more resistant to the toxic action of the chemicals as they recorded lower mortality rates. This result agrees well with Sanderson et al. ${ }^{13}$ on the potency of Zingiber officinale extract on both sexes of worms.

As the crude saponins proved to possess higher toxicity against $S$. mansoni worms than methanol extract and fractionation of the methanol extract lead to enhancement of the activity, therefore the potency of this plant could be attributed to the crude saponins which is the principal active component. This guided us to limit the chromatographic separation to the crude saponins and three compounds (I-III) were isolated by further purification.
When worms were subjected to $100 \mathrm{~g} / \mathrm{ml}$ of saponins I and II no mortality was noticed (Table 2), so these compounds can be considered inactive. As to saponin III, 100 $\mathrm{g} / \mathrm{ml}$ of this plant caused complete death of the worms after $2 \mathrm{hr}$. Microscopical observation showed that worms started to die even after only $1 / 2 \mathrm{hr}$. By lowering the concentration to 50 and $20 \mathrm{~g} / \mathrm{ml}$; and thereafter to 10 then $5 \mathrm{~g} / \mathrm{ml}$; worms were totally dead at $24 \mathrm{hr}$. These results clearly proved that saponins III is the compound responsible for the antischistosomal property of the plant. This minimum lethal concentration (5 $\mathrm{g} / \mathrm{ml}$ ) was markedly lower than concentrations reached by other authors of various botanical compounds against schistosomiasis worms in vitro; 200-1600 $\mathrm{g} / \mathrm{ml}^{12,23,24}$

Results on the impact of the three isolated saponins on B. alexandrina snails (Table 3) showed that saponins I and II are totally inactive up to $50 \mathrm{ppm}$ after $24 \mathrm{hr}$. While saponin III recorded higher molluscicidal effect as the $\mathrm{LC}_{50}$ and $\mathrm{LC}_{90}$ were 4.8 and $6 \mathrm{ppm}$ respectively. This result confirmed the previous study on the molluscicidal action of the extracts and crude saponins of this plant. ${ }^{11}$ 
Table 2: Effect of the isolated steroidal saponins (I-III) against adult S. mansoni worms in vitro.

\begin{tabular}{|c|c|c|c|c|c|c|c|}
\hline \multirow{3}{*}{ Compound } & \multirow{2}{*}{$\begin{array}{c}\text { Conc. } \\
(\mathrm{g} / \mathrm{ml})\end{array}$} & \multicolumn{6}{|c|}{$\begin{array}{c}\text { Mortality of worms after different } \\
\text { observation intervals (hrs) }\end{array}$} \\
\cline { 3 - 9 } & & \multicolumn{2}{|c|}{2} & \multicolumn{2}{|c|}{24} & \multicolumn{2}{c|}{48} \\
\cline { 3 - 8 } & & Female & Male & Female & Male & Female & Male \\
\hline Saponin I & 100 & 0 & 0 & 0 & 0 & 0 & 0 \\
\hline Saponin II & 100 & 0 & 0 & 0 & 0 & 0 & 0 \\
\hline & 100 & 100 & 100 & 100 & 100 & 100 & 100 \\
\cline { 2 - 9 } & 50 & 0 & 0 (weak & 100 & 100 & 100 & 100 \\
\cline { 2 - 9 } Saponin III & 20 & 0 & 0 & 100 & 100 & 100 & 100 \\
\cline { 2 - 9 } & 10 & 0 & 0 & 100 & 100 & 100 & 100 \\
\cline { 2 - 9 } & 5 & 0 & 0 & 100 & 100 & 100 & 100 \\
\hline Control & ----- & 0 & 0 & 0 & 0 & 0 & 0 \\
\hline \hline
\end{tabular}

Table 3: Effect of the saponins isolated from Furcraea selloea on adult Biomphalaria alexandrina after 24 hours exposure.

\begin{tabular}{||l|c|c|c|}
\hline Compound & $\begin{array}{c}\mathrm{LC}_{50}(\mathrm{ppm}) \\
\text { Confidence limits }\end{array}$ & LC $_{90}(\mathrm{ppm})$ & Slope \\
\hline Saponin I & \multicolumn{2}{|c|}{ - ve up to 50 ppm } \\
\hline Saponin II & \multicolumn{2}{|c|}{ - ve up to 50 ppm } \\
\hline Saponin III & $\begin{array}{c}4.8 \\
(4.391-5.546)\end{array}$ & 6 & 1.63 \\
\hline
\end{tabular}

The effect of $50 \mathrm{ppm}$ of saponin I and II and 6 ppm of saponin III was examined against hatchability of $S$. mansoni ova after different intervals (Table 4). Data showed that saponins I and II significantly reduced the hatchability of $S$. mansoni ova $(\mathrm{P}<0.05)$ till $3 / 4 \mathrm{hr}$. However after $1 \mathrm{hr}$, the reduction was insignificant from that of the control $(\mathrm{P}>0.05)$. Observation of the hatched miracidia showed that their movements started to slow down by $3 / 4 \mathrm{hr}$. As to ova exposed to $6 \mathrm{ppm}$ of saponin III, a very minor ratio of ova $(5 \%)$ hatched till the end of the observation period. This value is very significantly lower from the control $(\mathrm{P}<$ $0.001)$ and the dark color of the dead embryo can easily be noticed inside the eggs. While $80 \%$ of the control eggs hatched by the end of the observation period and the hatched miracidia swim very rapidly.

Very minor literatures reviewed the effect of isolated botanical compounds on larvae of schistosomiasis. ${ }^{25-26}$ In this study the effect of crude saponins and compound III on both larvae was remarkable (Tables 5 and 6) as 50 ppm of crude saponins killed $100 \%$ and $65 \%$ of miracidia and cercariae respectively. Meanwhile $6 \mathrm{ppm}$ of saponin III caused 100 and $79 \%$ death of both larvae respectively and this ratio was significantly variable from control. These results agree well with Lyddiard et $a l^{27}$ who reported on numerous biological potencies as antischistosomal, miracidicidal and molluscicidal bioactivity of isoflavonoids isolated from Millettis thonningii. From this data it can also be concluded that miracidia and cercariae were more susceptible to the tested saponins than the snails and this conclusion is in good accordance with other reported studies. ${ }^{28}$

The interesting finding about this plant is that it affects many stages of the parasite throughout the whole life cycle of schistosomiasis. So studying the effect of the dry plant powder on infection rate of snails was 
Table 4: Effect of the isolated saponins on the hatchability of S. mansoni eggs.

\begin{tabular}{|c|c|c|c|c||}
\hline \multirow{2}{*}{$\begin{array}{c}\text { Compound } \\
\text { Conc. (ppm) }\end{array}$} & \multicolumn{4}{|c|}{$\begin{array}{c}\text { Percent of S. mansoni eggs hatched after } \\
\text { different intervals and motion of miracidia }\end{array}$} \\
\cline { 2 - 5 } & $1 / 4$ & $1 / 2 \mathrm{~h}$ & $3 / 4 \mathrm{~h}$ & $1 \mathrm{~h}$ \\
\hline $\begin{array}{c}\text { Saponin I } \\
(50 \mathrm{ppm})\end{array}$ & $20 * \%$ & $30 * \%$ & $\begin{array}{c}37 * \%, \text { started to } \\
\text { slow }\end{array}$ & $\begin{array}{c}60 \%, \text { motion } \\
\text { slowed }\end{array}$ \\
\hline $\begin{array}{c}\text { Saponin II } \\
(50 \mathrm{ppm})\end{array}$ & $25 * \%$ & $50 \%$ & $\begin{array}{c}50 * \%, \text { started to } \\
\text { slow }\end{array}$ & $\begin{array}{c}70 \%, \text { motion } \\
\text { slowed }\end{array}$ \\
\hline $\begin{array}{c}\text { Saponin III } \\
(6 \mathrm{ppm})\end{array}$ & $5 * * * \%$ & $5 * * * \%$ & $\begin{array}{c}5 * * * \%, \text { Embryo } \\
\text { dead and opaque }\end{array}$ & $\begin{array}{c}5 * * * \%, \text { embryo } \\
\text { dead and opaque }\end{array}$ \\
\hline Control & $40 \%$ & $60 \%$ & $\begin{array}{c}80 \%, \text { motion very } \\
\text { fast }\end{array}$ & $\begin{array}{c}80 \%, \text { motion } \\
\text { very fast }\end{array}$ \\
\hline \hline
\end{tabular}

Table 5: Effect of the crude saponins and the isolated compounds (I-III) against miracidia of $S$. mansoni.

\begin{tabular}{|c|c|c|c|c|c|}
\hline \multirow{2}{*}{$\begin{array}{l}\text { Compound / } \\
\text { Conc. (ppm) }\end{array}$} & \multicolumn{5}{|c|}{$\%$ Mortality of miracidia after different intervals (hrs) } \\
\hline & $1 / 4$ & $1 / 2$ & $3 / 4$ & 1 & 2 \\
\hline $\begin{array}{c}\text { Crude saponins } \\
(50 \mathrm{ppm})\end{array}$ & $31 * * *$ & $48^{* *}$ & $66 * * *$ & $69 * * *$ & $100 * * *$ \\
\hline $\begin{array}{c}\text { Saponin I } \\
(50 \mathrm{ppm})\end{array}$ & 5 & 6 & 7 & 8 & 8 \\
\hline $\begin{array}{c}\text { Saponin II } \\
(50 \mathrm{ppm})\end{array}$ & 6 & 7 & 8 & 9 & 10 \\
\hline $\begin{array}{l}\text { Saponin III } \\
(6 \mathrm{ppm})\end{array}$ & $27 * * *$ & $43 * * *$ & $49 * * *$ & $56 * * *$ & $100 * * *$ \\
\hline Control & 3 & 5 & 7 & 8 & 9 \\
\hline
\end{tabular}

Table 6: Effect of the crude saponins and the isolated compounds (I-III) against cercariae of $S$. mansoni.

\begin{tabular}{|c|c|c|c|c|c|}
\hline \multirow{2}{*}{$\begin{array}{l}\text { Compound / } \\
\text { Conc. (ppm) }\end{array}$} & \multicolumn{5}{|c|}{$\%$ Mortality of cercariae after different intervals (hrs) } \\
\hline & $1 / 4$ & $1 / 2$ & $3 / 4$ & 1 & 2 \\
\hline $\begin{array}{l}\text { Crude saponins } \\
(50 \mathrm{ppm})\end{array}$ & $17 * * *$ & $25^{* *}$ & $33 * *$ & $47 * * *$ & $65 * * *$ \\
\hline $\begin{array}{c}\text { Saponin I } \\
(50 \mathrm{ppm})\end{array}$ & 5 & 7 & 7 & 11 & 12 \\
\hline $\begin{array}{c}\text { Saponin II } \\
(50 \mathrm{ppm})\end{array}$ & 4 & 5 & 8 & 10 & 13 \\
\hline $\begin{array}{c}\text { Saponin III } \\
(6 \mathrm{ppm})\end{array}$ & $16^{* * *}$ & $28 * *$ & $41 * * *$ & $58 * * *$ & $79 * * *$ \\
\hline Control & 4 & 6 & 7 & 9 & 11 \\
\hline
\end{tabular}

$* \mathrm{P}<0.05, * * \mathrm{p}<0.01, * * * \mathrm{p}<0.001$ 
recommended. Snails exposed to 20, 35 and 50 ppm of the dry plant powder 1-day preexposure to miracidia showed significant reduction in the ratio of infected snails. Meanwhile the infection rates of snails exposed to the same concentrations I day post-exposure to miracidia was more significantly depressed. This suppression in infection rates of snails treated with sublethal concentrations of the plant was inagreements with studies carried out on other molluscicidal plants. ${ }^{29,30}$ Moreover, El-Ansary et $a l .{ }^{31}$ reported that this depression in infection rate could be attributed to the inhibition in some enzymes with the subsequent disturbance of the glycolytic pathways responsible for the success of $B$. alexandrina sporocyst interaction (Table 7).

As to the acute toxicity of the methanol extract of the plant, the value of $\mathrm{LD}_{16}$ was $627.4 \mathrm{mg} / \mathrm{kg}$, LD50 was $4656.3 \mathrm{mg} / \mathrm{kg}$ and $\mathrm{LD}_{84}$ was $34555.8 \mathrm{mg} / \mathrm{kg}$ (Table 8). These high values proved the relative safety of this extract towards mammals, so the in vivo antischistosomal impact of it was studied.
Mice infected with $S$. mansoni were treated with $F$. selloea methanol extract either 2,4 or 7 weeks post infection which represents early immature, late immature and mature infection. The three groups received a single dose of $2500 \mathrm{mg} / \mathrm{kg}$ orally and showed a highly significant decrease in worm load at $p<0.01$ and $p<0.001$. The percents of reduction were $31.8,27.8$ and 31.4 for the three groups respectively (Table 9). It can also be noticed the high significant decrease in the total No. of coupled worms compared with the control. This means that the extract enhanced the separation of coupled worms which may lead to subsequent depression in No. of egg count. These results confirmed those obtained on the impact of the methanol extract on $S$. mansoni worms in vitro and is considered a great privilege of this plant over other plants. The bioactivity of Ginger ethyl acetate extract was determined in vitro at concentration of 200 $\mathrm{g} / \mathrm{ml}$, while oral and subcutaneous delivery of this extract produced no significant reduction in worm numbers. ${ }^{13}$

Table 7: Effect of sublethal concentrations of Furcraea selloea dry powder on infectivity of B.alexandrina snails with $S$. mansoni miracidia.

\begin{tabular}{|c|c|c|c|c|c|c||}
\hline \multirow{2}{*}{ Plant treatment } & \multirow{2}{*}{$\begin{array}{c}\text { Plant con. } \\
(\mathrm{ppm})\end{array}$} & \multirow{2}{*}{$\begin{array}{c}\text { No. of } \\
\text { exposed } \\
\text { snails }\end{array}$} & \multicolumn{2}{|c|}{$\begin{array}{c}\text { Snails surviving } \\
\text { first shedding }\end{array}$} & \multicolumn{2}{|c|}{ Infected snails } \\
\cline { 3 - 8 } & & No. & $\%$ & No. & $\%$ \\
\hline Control & - & 30 & 28 & 93.3 & 23 & 82.1 \\
\hline \multirow{2}{*}{$\begin{array}{c}\text { 1 day pre-exposure } \\
\text { to miracidia }\end{array}$} & 20 & 30 & 26 & 86.7 & 19 & $73.1^{*}$ \\
\cline { 2 - 8 } & 35 & 30 & 23 & $76.7^{*}$ & 17 & $73.9^{*}$ \\
\cline { 2 - 8 } & 50 & 30 & 21 & $70.0^{*}$ & 15 & $71.4^{*}$ \\
\hline $\begin{array}{c}1 \text { day post-exposure } \\
\text { to miracidia }\end{array}$ & 20 & 30 & 25 & 83.3 & 13 & $52.0^{* *}$ \\
\cline { 2 - 8 } & 35 & 30 & 24 & 80.0 & 10 & $41.7^{* * *}$ \\
\cline { 2 - 8 } & 50 & 30 & 20 & $66.7^{* *}$ & 6 & $30.0^{* * *}$ \\
\hline
\end{tabular}

$* \mathrm{P}<0.05, * * \mathrm{p}<0.01, * * * \mathrm{p}<0.001$

Table 8: Acute toxicity of $F$. selloea methanol extract on albino mice.

\begin{tabular}{|c|c|c|c|c|}
\hline \hline Dose & $\begin{array}{c}\text { No of } \\
\text { animals }\end{array}$ & $\begin{array}{c}\text { No of } \\
\text { mortality }\end{array}$ & $\begin{array}{c}\% \\
\text { Mortality }\end{array}$ & Calculated LD \\
\hline $500 \mathrm{mg} / \mathrm{kg}$ & 6 & 1 & 16.66 & $\mathrm{LD}_{16}=627.4 \mathrm{mg} / \mathrm{kg}$ \\
\hline $1000 \mathrm{mg} / \mathrm{kg}$ & 6 & 1 & 16.66 & $\mathrm{LD}_{50}=4656.3 \mathrm{mg} / \mathrm{kg}$ \\
\hline $2000 \mathrm{mg} / \mathrm{kg}$ & 6 & 2 & 33.33 & $\mathrm{LD}_{84}=34555.8 \mathrm{mg} / \mathrm{kg}$ \\
\hline $4000 \mathrm{mg} / \mathrm{kg}$ & 6 & 3 & 50.00 & \\
\hline
\end{tabular}


Table 9: Effect of F. selloea extract on worm load in mice infected with $S$ mansoni and sacrificed 9 weeks post infection.

\begin{tabular}{|c|c|c|c|c|c|c|}
\hline \multirow[b]{2}{*}{$\begin{array}{l}\text { Animal group } \\
\text { (No of animals) }\end{array}$} & \multirow[b]{2}{*}{ Dose } & \multicolumn{3}{|c|}{ Worm count } & \multirow[b]{2}{*}{$\begin{array}{c}\text { Total No. } \\
\text { of Worms } \\
\text { X } \pm \text { SE }\end{array}$} & \multirow[b]{2}{*}{$\%$ Reduction } \\
\hline & & $\begin{array}{l}\text { No. of } \\
\text { Males } \\
X \pm \text { SE }\end{array}$ & $\begin{array}{c}\text { No. of } \\
\text { Females } \\
\mathrm{X} \pm \mathrm{SE}\end{array}$ & $\begin{array}{c}\text { No. of } \\
\text { Couples } \\
\mathrm{X} \pm \text { SE }\end{array}$ & & \\
\hline $\begin{array}{l}\text { Untreated } \\
\text { control (10) }\end{array}$ & - & $7.4 \pm 0.4$ & $5.1 \pm 1.1$ & $6.0 \pm 0.5$ & $24.5 \pm 0.92$ & \\
\hline $\begin{array}{l}2 \text { weeks post } \\
\text { infection (6) }\end{array}$ & $\begin{array}{c}2500 \\
\mathrm{mg} / \mathrm{kg}\end{array}$ & $6.3 \pm 1.5$ & $3.5 \pm 0.6$ & $\begin{array}{c}3.5 \pm 0.6 \\
* *\end{array}$ & $\begin{array}{c}16.7 \pm 1.2 \\
* * *\end{array}$ & $31.8 \%$ \\
\hline $\begin{array}{l}4 \text { weeks post } \\
\text { infection (6) }\end{array}$ & $\begin{array}{c}2500 \\
\mathrm{mg} / \mathrm{kg}\end{array}$ & $6.2 \pm 1.3$ & $2.8 \pm 1.0$ & $4.3 \pm 1.1$ & $\begin{array}{c}17.7 \pm 1.4 \\
* *\end{array}$ & $27.8 \%$ \\
\hline $\begin{array}{l}7 \text { weeks post } \\
\text { infection (6) }\end{array}$ & $\begin{array}{c}2500 \\
\mathrm{mg} / \mathrm{kg}\end{array}$ & $3.5 \pm 1.0$ & $8.2 \pm 1.7$ & $\begin{array}{c}2.5 \pm 0.7 \\
* *\end{array}$ & $\begin{array}{c}16.8 \pm 1.3 \\
* * *\end{array}$ & $31.4 \%$ \\
\hline
\end{tabular}

*Significant differences versus untreated control

$* * \mathrm{p}<0.01, * * * \mathrm{p}<0.001$

Finally it can be concluded that these preliminary results on the action of this plant extract in reducing worm load is promising and needs a follow up comprehensive studies on this plant and other species for the hope of reaching a botanical, safe and potent antischistosomal drug.

\section{Fractionation and purification results}

The isolated compounds were identified guided by the obtained spectroscopic and chemical data as follows:

Saponin I, was obtained as an amorphous solid with the molecular formula $\mathrm{C}_{39} \mathrm{H}_{64} \mathrm{O}_{14}$. This was deduced by appearance of the molecular ion peak $[\mathrm{M}+\mathrm{H}]$ at $\mathrm{m} / \mathrm{z} 757$ in CI-MS spectrum and from the ${ }^{13} \mathrm{C}$ - NMR spectrum (Tables 10 and 11) with 39 signals which were divided into 27 carbon signals due to aglycone part and 12 carbon signals for the two sugar moieties. Saponin I gave a negative reaction with Ehrlich reagent. ${ }^{32-34}$ The glycoside nature of saponin $\mathbf{I}$ was obtained from the strong absorption bands at 3401 and $1069 \mathrm{~cm}^{-1}$ in IR spectrum. ${ }^{32,33}$

The ${ }^{1}$ HNMR spectrum showed signals for two tertiary methyl groups at $\delta 0.78$ and 0.88 [each, s], two secondary methyl groups at $\delta$ 0.71 and 1.12 [each, d] and two anomeric protons at $\delta 4.80$ and 4.88 [each, d] ${ }^{33,34}$ The presence of disaccharide moiety was indicated by appearing the fragment ion peaks at 757 $\left[\mathrm{M}^{+}+\mathrm{H}\right], 595\left[\mathrm{M}^{+}+\mathrm{H}-\mathrm{Glc}\right]$ and $433\left[\mathrm{M}^{+}+\mathrm{H}-2\right.$ Glc] in CI-MS spectrum as well as two
Table 10: ${ }^{13} \mathrm{C}-\mathrm{NMR}$ spectral data of the aglycone parts of saponins I-III (In DMSO- $\mathrm{d}_{6} ; \quad$ TMS as internal standard).

\begin{tabular}{|c|c|c|c||}
\hline $\begin{array}{c}\text { Carbon } \\
\text { No. }\end{array}$ & $\begin{array}{c}\text { Saponin } \\
\text { I }\end{array}$ & $\begin{array}{c}\text { Saponin } \\
\text { II }\end{array}$ & $\begin{array}{c}\text { Saponin } \\
\text { III }\end{array}$ \\
\hline 1 & 38.67 & 45.12 & 37.40 \\
\hline 2 & 30.99 & 70.24 & 29.35 \\
\hline 3 & 70.24 & 84.33 & 77.60 \\
\hline 4 & 33.40 & 34.65 & 34.45 \\
\hline 5 & 49.84 & 44.50 & 44.30 \\
\hline 6 & 78.76 & 27.29 & 28.50 \\
\hline 7 & 41.18 & 33.35 & 31.30 \\
\hline 8 & 34.60 & 36.20 & 33.90 \\
\hline 9 & 53.08 & 53.11 & 55.80 \\
\hline 10 & 36.20 & 36.92 & 35.85 \\
\hline 11 & 20.53 & 20.55 & 38.73 \\
\hline 12 & 40.15 & 40.39 & 212.40 \\
\hline 13 & 40.43 & 40.60 & 55.60 \\
\hline 14 & 55.56 & 55.53 & 56.40 \\
\hline 15 & 32.10 & 31.50 & 31.70 \\
\hline 16 & 81.40 & 81.24 & 79.90 \\
\hline 17 & 63.89 & 63.20 & 54.41 \\
\hline 18 & 16.71 & 16.31 & 17.12 \\
\hline 19 & 13.19 & 14.30 & 11.57 \\
\hline 20 & 42.81 & 42.20 & 42.90 \\
\hline 21 & 16.21 & 14.70 & 13.43 \\
\hline 22 & 108.41 & 110.45 & 108.46 \\
\hline 23 & 31.51 & 30.73 & 30.60 \\
\hline 24 & 28.87 & 23.80 & 28.50 \\
\hline 25 & 29.88 & 39.28 & 29.40 \\
\hline 26 & 66.06 & 64.96 & 65.40 \\
\hline 27 & 17.13 & 65.89 & 17.20 \\
\hline & & & \\
\hline
\end{tabular}


Table 11: ${ }^{13} \mathrm{C}-\mathrm{NMR}$ spectral data of the sugar moieties of saponins I-III (In DMSO- $\mathrm{d}_{6}$; TMS as internal standard).

\begin{tabular}{|c|c|c|c|}
\hline $\begin{array}{c}\text { Carbon } \\
\text { No. }\end{array}$ & Saponin I & Saponin II & Saponin III \\
\hline 1 & $-60-\mathrm{Glc}$ & $-30-\mathrm{Glc}$ & $-30-\mathrm{Glc}$ \\
\hline 2 & 99.43 & 99.54 & 101.60 \\
\hline 3 & 73.63 & 73.63 & 75.60 \\
\hline 4 & 75.43 & 75.43 & 87.50 \\
\hline 5 & 80.18 & 80.47 & 70.45 \\
\hline 6 & 76.42 & 76.52 & 76.25 \\
\hline & 61.22 & 61.22 & 61.52 \\
\hline 1 & 104.54 & Glc $(1-4) \mathrm{Glc}$ & $\mathrm{Glc}(1-3) \mathrm{Glc}$ \\
\hline 2 & 76.52 & 104.46 & 102.50 \\
\hline 3 & 78.76 & 73.93 & 74.90 \\
\hline 4 & 70.30 & 70.24 & 86.60 \\
\hline 5 & 76.77 & 76.77 & 69.55 \\
\hline 6 & 61.41 & 61.40 & 77.45 \\
\hline & & & 62.30 \\
\hline 1 & & & $\mathrm{Xy}(1-3) \mathrm{Glc}$ \\
\hline 2 & & & 75.60 \\
\hline 3 & & & 78.81 \\
\hline 4 & & & 67.45 \\
\hline 5 & & & \\
\hline
\end{tabular}

characteristic signals of two anomeric carbon signals of the two sugar moieties at $\delta 99.43$ and 104.54 in ${ }^{13} \mathrm{C}-\mathrm{NMR}$ spectrum. ${ }^{34-37}$

Acid hydrolysis of saponin I gave steroidal sapogenin which was identified as chlorogenin by comparing of its IR and ${ }^{13} \mathrm{C}$ NMR spectra with the reported data of original chlorogenin signals. ${ }^{34-36}$ The dissacharide was concluded to be linked to the C-6 hydroxyl position of the aglycone because in the ${ }^{13} \mathrm{C}$ NMR spectrum of saponin $\mathbf{I}$ the signal due to C-6 was shifted to a lower field by $10.76 \mathrm{ppm}$ whereas the signals due to C-5 and C-7 moved to upper fields by 1.96 and $1.72 \mathrm{ppm}$ as compared with those of chlorogenin signals. ${ }^{32,34,35,37}$

The structure of saponin I based upon a (25R)-spirostanol derivatives, this was suggested by presence of its characteristic bands in the IR spectrum at 921, 898 and 865 $\mathrm{Cm}^{-1}$ where the intensity of band at 898 was greater than the band at $921 \mathrm{Cm}^{-1} \cdot 32,34,35$ The ${ }^{13} \mathrm{C}$-NMR signals of the disaccharide moiety of saponin I revealed that $\mathrm{C}-4$ of the inner glucose was shifted down field at $\delta 80.18$ indicating that the terminal glucosyl unit was linked to the inner glucose unit through $\mathrm{C} 4-\mathrm{OH}$ of this glucose unit. ${ }^{32-34}$ Therefore, the structure of saponin I was formulated as 6-O- $\beta$-Dglucopyranosyl $\quad(1 \rightarrow 4)-\beta$-D-glucopyranoside chlorogenin.

Saponin II, gave a negative reaction with Ehrlich reagent and showed broad absorption bands in its IR spectrum at 3400 and $1067 \mathrm{~cm}^{-1}$ indicating that this saponin has spirostanol glycoside structure. Also the characteristic bands of $25 \mathrm{~S}$ spirostane steroidal species were appeared at 918, 897 and 865 where the intensity of the band at 918 is greater than the band at $897 .^{32-35}$ The appearing of the molecular ion peak in CI-MS spectrum at $\mathrm{m} / \mathrm{z}$ $755\left[\mathrm{M}^{+}+\mathrm{H}\right]$ exhibited the molecular weigh is 754. Also, the two fragment ion peaks at 594 $\left[\mathrm{M}^{+}+\mathrm{H}-\mathrm{Glc}\right]$ and $431 \quad\left[\mathrm{M}^{+}+\mathrm{H}-2 \mathrm{Glc}\right]$ were corresponding to the loss of two glucose units. ${ }^{36,37}$ This was supported by appearing of 
two anomeric carbon signals at $\delta 99.54$ and 104.46 in its ${ }^{13} \mathrm{C}-\mathrm{NMR}$ spectrum. ${ }^{38-40}$ The ${ }^{1}$ HNMR spectrum of saponin II showed the proton signals attributed to the C-18, C-19 methyl groups at $\delta 0.75$ and 0.85 (each, s) as well as methyl group of $\mathrm{C} 21$ at $\delta 1.12$ and C-27 methyl at range between at $\delta 3.63-3.68 .^{40,41}$ Also, in ${ }^{1} \mathrm{HNMR}$ spectrum the two anomeric proton signals appeared at $\delta 4.84$ and 4.94 (each, $d$ ) representative of the $\beta$ - configuration of the two sugar units. ${ }^{39,41}$

On comparison between $\mathrm{H}$ and C-NMR spectra of saponin II with those of saponin isolated previously from the leaves of Digitalis conaripnsis and from the seeds of Allium tuberosum, it was observed that the aglycone signals of saponin II were in good agreement with crestagenin $(2 \alpha, 3 \beta, 5 \alpha, 25 \mathrm{~S})$ - spirostan2, 3, 27-triol signals. ${ }^{41-43}$ The linkage of the sugar chain was concluded to be at the C-3 hydroxyl position of the aglycone because, in the ${ }^{13} \mathrm{C}$-NMR spectrum of saponin II, the signal due to $\mathrm{C}-3$ shifted lower field by $\delta 7.9$ whereas the signals due to $\mathrm{C}-2$ and $\mathrm{C}-4$ moved to upper fields by 2.86 and $2.75 \mathrm{ppm}$ as compared with three carbon signals of original crestagenin. ${ }^{32,41}$

The interglycosidic linkage between the two sugar units of the dissaccharide of this compound was deduced from the down field shift of C-4 of the inner glucose at $\delta 80.47$ in the ${ }^{13} \mathrm{C}$-NMR spectrum. ${ }^{39-41}$ From the above data, the structure of saponin II was elucidated as 3-O- $\beta$-D-glucopyranosyl-( $1 \rightarrow 4)-\beta$-D-glucopyranoside crestagenin.

Saponin III, was crystallized in the form of fine needles from methanol and gave a negative reaction with Ehrlish reagent. ${ }^{34,35}$ The appearing of the ion peak at $\mathrm{m} / \mathrm{z} 887\left[\mathrm{M}^{+}+\mathrm{H}\right]$ in the CI-MS spectrum indicating that the molecular weight of this saponin was 886 . Also the fragment ion peaks at m/z 412 and 394 were suggestive of a saturated monohydroxyl spirostane nucleus. ${ }^{37,41}$ The IR spectrum exhibited strong absorption bands at $\delta 920,898$ and $812 \mathrm{Cm}^{-1}$ characteristic for the spirostane steroidal saponins. Weaker intensity of the band $920 \mathrm{Cm}^{-1}$ than $898 \mathrm{Cm}^{-1}$ showed that the saponin III belongs to $25 \mathrm{R}$ series of spirostanes. ${ }^{41-43}$ Also the absorption band at $1705 \mathrm{Cm}^{-1}$ in the IR spectrum of saponin III and a ${ }^{12} \mathrm{C}$-resonance at $\delta 212.40$ in the ${ }^{13} \mathrm{C}$ NMR confirmed the presence of carbonyl carbon and its position at C-12. ${ }^{43-44}$ Also ${ }^{13} \mathrm{C}$ NMR spectrum showed signals of 44 carbons, 27 of which arose from the aglycone moiety whereas 17 carbon signals for three sugar units. ${ }^{37-44}$ The carbon signals of aglycone part were in good agreement with those reported in the literature of gloriogenin $[(25 \mathrm{R})-3-\beta$ hydroxy- $5 \beta$ spirostan-12-one]. ${ }^{1,3,14}$ Fragment ions at $\mathrm{m} / \mathrm{z} 725\left[\mathrm{M}^{+}+\mathrm{H}-\mathrm{Glc}\right], 593\left[\mathrm{M}^{+}+\mathrm{H}-\mathrm{Glc}-\right.$ $\mathrm{Xyl}]$ and $431\left[\mathrm{M}^{+}+\mathrm{H}-2 \mathrm{Glc}-\mathrm{Xyl}\right]$ reflected the loss of three sugar units, two of them are glucose units and one is xylose unit. ${ }^{44,46}$

The point of attachment of the trisaccharide part with the aglycone part and the interglycosidic linkages between the sugar units were established by ${ }^{13} \mathrm{C}-\mathrm{NMR}$ spectrum where C-3 of the aglycone part was shifted at downfield at $\delta 77.60$ indicating, the trisccharide was linked with the aglycone part through $\mathrm{OH}$ at this carbon. Also, each of C-3 of the two inner glucose units were shifted at down field $\delta 87.50$ and 86.60 reflecting that the two carbons are positions of sugar linkage and the xylose unit is outer sugar unit. ${ }^{44-46}$ From the above data, the structure of saponin III was identified as 3-O- $\beta$-D-glucopyranosyl-( $(\rightarrow 3)$ $\beta$-D-glucopyranosyl-( $1 \rightarrow 3)-\beta$-D-xylopyranoside gloriogenin.

We can finally conclude that in this study, the activity guided isolation of saponins of $F$. selloea lead to separation of a steroidal saponin compound (III) that accounts in part, for the observed antischistosomal and other biological potentials of this plant.

\section{REFERENCES}

1- M. Eddlestan and S. Pierini, "Oxford Handbook of Tropical Medicine", Oxford: Oxford University Press (1999).

2- X. Shuhua and J. Chollet, Parasitol. Int., 49, 19 (2000).

3- G. C. Coles, W. T. Mutahi, G. K. Kinoti, J. I. Bruce and N. Kotz, Trans. Roy. Soc. Trop. Hyg., 81, 782 (1987).

4- N. Katz, R. S. Rocha, De Souza; P. Cecilia, P. C. Filho, J. I. Bruce, C. C. Cades and G. Kinoti, Am. J. Trop. Med. Hyg., 44, 509 (1991).

5- F. F. Stelma, I. Talla, S. Sow, A. Kongs, M. Niang, K. B. Polman, A. M. Deelder and B. Gryseels, Am. J. Trop. Med. Hyg., 53, 167 (1995). 
6- P. G. Fallon, J. S. Mubarak, R. E. Fookes, M. Niang, A. E. Butterworth, R. F. Sturrock and M. J. Doenhoff, Exp. Parasitol., 86, 29 (1997).

7- M. M. Ismail, A. A. Metwally, A. Farghally, J. I. Bruce, L. F. Tao and J. L. Bennett, Am. J. Trop. Med. Hyg., 55, 214 (1996).

8- J. D. Phillipson, Trans R., Soc. Trop. Med. Hyg., 88, 17 (1994).

9- L. X. Liu and P. F. Weller, Antiparasitic drugs. N. Engl. J. Med., 334, 1178 (1996).

10- V. Schulz, R. Hansel and V. E. Tyler, Rational Phytotherapy, "A Physicians Guide to Herbal Medicine", Berlin. Springer (1997).

11- M. M. El-Sayed, H. A. El-Nahas, E. A. ElWakil and M. A. El-Shazly, Women's College Ann. Rev., 21, 55 (2001-2002).

12- S. Jiwajinda, V. Santisopasri, A. Murakami, H. M. Kawanaka, M. Gasquet, R. Eilas, G. Balansard and H. Ohigashi, Asia J. Ethnopharmacol., 82, 55 (2002).

13- L. Sanderson, A. Bartlett and P. J. Whitfield, J. Helminthol., 76, 241 (2002).

14- WHO: Molluscicides Screening and Evaluation, Bull. Wld. Hlth., Org., 33, 567 (1965).

15- J. T. Litchfield, and F. E. Wilcoxon, J. Pharm. Exp. Ther., 96, 99 (1949).

16- A. M. El-Ridi, M. El-Gindy, M. Arafa and A. Fargly, J. Egypt. Soc. Parasitol., 13, 155 (1983).

17- P. B. Tchunwou, A. J. Englande, E. Malek, A. C. Anderson and A. Abdel Ghani, J. Environ. Sci. Hlth. Pest. Food Contam. Agric. Wastes, 26, 69 (1991).

18- A. H. Ahmed and R. M. Ramzy, Ann. Top. Med. Parasit., 91, 931 (1997).

19- F. M. El-Assal, N. M. Shoukry, G. N. Soliman and N. S. Mansour, J. Egypt. Soc. Parasitol., 27, 739 (1997).

20- R. H. Duvall and W. B. De Witt, Am. J. Trop. Med. Hyg., 16, 483 (1967).

21- D. Schwartz, "Methods Statisques al usage Des Medicines et Des Biologists", Flam Marion, Paris, 1963, pp. 143, 191.

22- S. Perrett and P. J. Whitfield, Planta Medica, 61, 267 (1995).

23- P. Molgaard, S. B. Nielsen, D. E. Rasmussen, R. B. Drummond, N. Makaza and J. Andereson, J. Ethnopharmacol., 74, 257 (2001).
24- S. G. Sparg, J. Van Staden and A. K. Jager, J. Ethnopharmacol., 73, 209 (2000).

25- S. A. Mansour, E. A. El-Khrisy and N. F. Abdel- Hamid. Egypt. J. Schist. Infect. Enden. Dis., 25, 15 (2003a).

26- S. A. Mansour, E. A. El-Khrisy and N. F. Abdel-Hamid, Egypt. J. Schist. Infect. Enden. Dis., 25, 41 (2003b).

27- J. R. Lyddiard, P. J. Whitfield and A. Barlett, J. Parasitol., 88, 163 (2002).

28- H. A. El-Nahas, Az. J. Pharm. Sci., 28, 63 (2001).

29- B. B. Mostafa and A. A. Tannstawy, J. Egypt Soc. Parasitol., 30, 929 (2000).

30- A. A. Tantawy, B. B. Mostafa and Sharaf El-Din: J. Biomed. Sci., 14, 183 (2004).

31- A. El-Ansary, S. El-Bardicy, M. S. Solimen and N. Zayed, J. Egypt. Soc. Parasitol., 30, 809 (2000).

32- M. Kieroda, Y. Mimaki, F. Hasegawa, A. Yokosuka, Y. Sashida and H. Sakagami, Chem. Pharm. Bull., 49, 726 (2001).

33- O. P. Sati and G. Pant, J. Nat. Products, 48, 395 (1985).

34- Mimaki, Y., Sashida, Y. and K. Kawashima, Phytochemistry, 30, 3721 (1991).

35- A. Yokosuka, Y. Mimaki, M. Kuroda and Y. Sashida, Plant. Med., 66, 393 (2000).

36- S. C. Sharma and O. P. Sati, Phytochemistry, 21, 1820 (1982).

37- M. M. Abdel-Gawad, M. M. El- Sayed, H. A. El-Nahas and E. S. Abdel-Hameed, Bull. Fac. Pharm. Cairo Univ., 42, 173 (2004).

38- Y. Mimaki, Y. Takaashi, M. Kuroda and Y. Sashida, Phytochemistry, 45, 1229 (1997).

39- S. Yahara, T. Ura, C. Sakamoto and T. Nohara, Phytochemistry, 37, 831 (1994).

40- Y. Ding, Y.Y. Chem, D. Wang and C. Yang, Phytochemistry, 28, 2787 (1989).

41- Z. M. Zou, D. Q. Yu and P. Z.. Cong, Phytochemistry, 57, 1219 (2001).

42- B. J. Dolgado, J. M. Velanzquez, J. L. Bretion Fumes, An. Quim 65, 817 (1969).

43- A. G. Gonzalez, V. Darias, M. C. Suarez, K. Janssess, Farmaco. Sci., 38, 3 (1983).

44- A. Debella, E. Haslinger, O. Kunert, G. Michl and D. Abebe, Phytochemistry 51, 1069 (1999). 
45- K. Nakanu, Y. Midznta, Y. Hara, K. Murakami, Y. Takaishi and T. Tomimatsu, Phytochemistry, 30, 633 (1991).
46- Y. Xu, H. S. Chen, H. Q. Liony, Z. B. Gu, W. Y. Li, W. N. Leng and T. J. Li, Planta Med., 66, 545 (2000). 